\title{
Productivity and competitiveness in medium-large forestry-furniture and automotive companies in the Municipality of Durango, Dgo.
}

\section{La productividad y competitividad en empresas forestales-muebleras y automotrices medianas-grandes en el Municipio de Durango, Dgo.}

CHAVEZ-SAMANIEGO, Rosendo†๋*, GUTIERREZ-MUÑOZ, Israel Iván and GRIJALVA-AVILA, Gerardo

Universidad Politécnica de Durango, Carretera Durango-México km 9.5 S/N, poblado Dolores Hidalgo C.P. 34300 Durango, Dgo. Mexico.

ID $1^{\text {st }}$ Author: Rosendo, Chávez-Samaniego / ORC ID: 0000-0001-8402-9502, CVU CONACYT ID: 224240

ID $1^{\text {st }}$ Coauthor: Israel Iván, Gutiérrez-Muñoz / ORC ID: 0000-0002-8496-8849, CVU CONACYT ID: 404498

ID $2^{\text {nd }}$ Coauthor: Gerardo, Grijalva-Ávila / ORC ID: 0000-0002-3402-3556, CVU CONACYT ID: 276466

DOI: $10.35429 / J M P C .2020 .18 .6 .10 .21$

Received: July 18; Accepted: December 30, 2020

\begin{abstract}
The research determines the factors and dimensions that influence the productivity and competitiveness of medium-large companies in the forestry-furniture and automotive sector of the Municipality of Durango, in turn allowing these factors and dimensions to be transferred to a validated instrument. Technology support streamlines the analysis of the information that companies provide to determine the level of productivity and competitiveness. Know the status of companies with their various internal indicators, it shows the need to deploy an empirical study that involves variables and factors, which in turn allows to be Analyzed the results to establish clear and objective strategies all through a Web application. The validity of the instrument content with the V-Aiken methodology with value of .845 and the reliability of the Cronbach's alpha instrument $\alpha=.912$ allows the instrument to be applied to obtain the Productivity Level 4.4 and the Competitiveness Level 3.8 in one scale of 0 to 5 .
\end{abstract}

\section{Resumen}

La investigación determina los factores y dimensiones que influyen en la productividad y competitividad de las empresas medianas-grandes del sector forestal-mueblero y automotriz del Municipio de Durango, a su vez permita transferir esos factores y dimensiones a un instrumento validado. El apoyo tecnológico agiliza el análisis de la información que las empresas proporcionan para determinar el nivel de productividad y competitividad. Conocer el estatus que encierran las empresas con sus diversos indicadores internos, muestra la necesidad de desplegar un estudio empírico que involucre las variables y factores, que a su vez permita ser analizados los resultados para establecer estrategias claras y objetivas todo mediante una aplicación Web. La validez del contenido del instrumento la metodología V-Aiken con valor de .845 y la fiabilidad del instrumento Alfa de Cronbach $\alpha=.912$ permite aplicar el instrumento para obtener Nivel de Productividad 4.4 y el Nivel de Competitividad 3.8 en una escala de 0 a 5 .

Productividad, Competitividad, Factores

\footnotetext{
* Correspondence to the Author (Email: Rosendo.chavez@ unipolidgo.edu.mx)

$\dagger$ Researcher contributing as first author.
} 


\section{Introduction}

The World Economic Forum (WEF) publishes in Geneva Switzerland, the 2019 report on Global Competitiveness for the year 2019, signed by Klaus Schwab. It is the leading report on the engines of long-term growth. This year it includes 141 economies (99\% of world GDP and $94 \%$ of world population).

According to the OECD in November 2019, it maintains that the global outlook remains fragile and unstable. World GDP growth has fallen to $2.9 \%$ this year - its lowest level since the financial crisis - and is projected to remain at $3 \%$ for the next two years.

According to the OECD, it mentions that governments must cooperate and invest to prevent a long-term stagnation phase. Coordinated and urgent political measures are needed to establish trust, boost inclusive growth and raise living standards. That said, it is an unprecedented challenge for Mexico and for the rest of the Latin countries, their current decisions will mark their uncertainty in economic growth.

The WEF believes that sustained economic growth remains the surest way out of poverty and a central driver of human development; Through competitiveness indices (global, national and urban), IMCO seeks to provide useful information for the design, monitoring and follow-up of national public policies for competitiveness and economic development in Mexico. In this sense, they mention "Mexico, dreams without opportunity", which is a greater challenge for generating, attracting and retaining talent and investment that detonate productivity and well-being.

Most of the States, governments work in isolation from companies, normally when a company is established, the government offers all services. However, the development and sustainability depends solely on the company, they regularly review their indicators and focus their efforts on improving them. But it is important to have an instrument that allows evaluating them under a general approach with dimensions that allow knowing the level of productivity and competitiveness.
For this reason, this research aims to support companies and obtain information that allows us to know their level of productivity and competitiveness, even more so to provide the organization with graphics, analysis and a strategic plan to monitor and take action.

\section{Issue}

The existence of different instruments to measure the competitiveness of a state or a country is complex and alien to a company. The organization does not derive any benefit from such measurements, and even others are unaware of them. The instruments consider very general factors that impact society, government and business. Therefore, local companies do not know their level of productivity and competitiveness among themselves, nor between their line of business or sector.

\section{Objective}

Determine the factors and dimensions that must be considered to generate a reliable instrument that allows measuring the level of productivity and competitiveness of an organization with the technological application.

\section{Background}

Competitiveness is based on pillars that the countries themselves define according to their environment, area and culture; This allows them to achieve achievements in terms of competitiveness and in some cases stand out from a backward situation, to an economic power, counting on their highly trained human resources that innovate processes thanks to their technological preparation.

Electronic industry companies are highly relevant to the Korean economy, their share of total exports being over $28 \%$ by the way. Another outstanding and competitive industry in South Korea is the automotive industry, this industry is among the main automobile producers in the world, with the companies Hyundai, Kia, Daewoo and Samsung gaining market leadership (Lim, 2003), which had a growth of over 50\% from 2001 to 2012.

Factors South Korea involves to increase productivity: 
- $\quad$ They use their natural resources.

- $\quad$ They use financial resources.

- Employ human resources.

- $\quad$ Key factor is price.

- $\quad$ Markets.

- Infrastructure.

- Innovation.

- Higher education.

- Training.

Manufacturing MSMEs have been the object of studies with innovation approaches with different results and sometimes concurrent in different countries; However, they consider five strategic levels in common.

The efforts of Ecuadorian and Argentine companies rely on innovation to be more competitive and define the following variables.

\begin{tabular}{|c|c|}
\hline Variables & Factors \\
\hline Dependents & $\begin{array}{l}\text { Product innovation } \\
\text { Process innovation }\end{array}$ \\
\hline Independent & $\begin{array}{l}\text { Research and development } \\
\text { Quality } \\
\text { Qualified Human Resources }\end{array}$ \\
\hline Quantitative & $\begin{array}{l}\text { Sales } \\
\text { Exports } \\
\text { Job } \\
\text { Specialized workforce } \\
\text { Productivity }\end{array}$ \\
\hline Qualitative & $\begin{array}{l}\text { New goods and services offered } \\
\text { Opening new markets } \\
\text { Costs reduction } \\
\text { Energy reduction } \\
\text { Obtaining quality or export } \\
\text { certifications }\end{array}$ \\
\hline Control & $\begin{array}{l}\text { Antiquity } \\
\text { Size } \\
\text { External financing } \\
\text { Owner Features } \\
\text { Competition } \\
\end{array}$ \\
\hline
\end{tabular}

Table 1 Variables of innovation Source: Peirano (2014)

The organization for economic cooperation and development "OECD" defines the following factors to measure the productivity of countries.

\begin{tabular}{|c|c|}
\hline & \\
\hline $\begin{array}{l}\text { Macroeconomics } \\
\text { and finance }\end{array}$ & $\begin{array}{l}\text { Democratic state to persecute, } \\
\text { sanction and socially insert; } \\
\text { Maintain social peace, quality of } \\
\text { life and the investment } \\
\text { environment. }\end{array}$ \\
\hline $\begin{array}{l}\text { ducation } \\
\text { ealth }\end{array}$ & $\begin{array}{l}\text { inclusion and generating human } \\
\text { capital, includes indicators of } \\
\text { poverty, inequality, academic } \\
\text { performance, medical supply, } \\
\text { health services and socio-economic } \\
\text { conditions. }\end{array}$ \\
\hline $\begin{array}{lr}\begin{array}{l}\text { ommerce, } \\
\text { rowth } \\
\text { overnment }\end{array} & \text { and } \\
\end{array}$ & $\begin{array}{|lr|}\text { Stable and functional political } \\
\text { systems, democratic, } & \text { healthy } \\
\text { competition, greater } & \text { citizen } \\
\text { participation, corruption and ethics. }\end{array}$ \\
\hline $10 \mathrm{~ns}$ & workers and emp \\
\hline ade & $\begin{array}{l}\text { your relati } \\
\text { urism and ca }\end{array}$ \\
\hline Tran & transs \\
\hline $\begin{array}{l}\text { idustry, services } \\
\text { ad } \\
\text { htrepreneurship }\end{array}$ & $\begin{array}{l}\text { Even floor for companies to } \\
\text { compete, innovate, settle, product } \\
\text { and price. }\end{array}$ \\
\hline $\begin{array}{l}\text { ience, technology } \\
\text { d innovation }\end{array}$ & $\begin{array}{l}\text { Ability to innovate, quantity and } \\
\text { quality; formal research, patents, } \\
\text { technological development, } \\
\text { creativity and diversity. }\end{array}$ \\
\hline $\begin{array}{l}\text { mployment } \\
\text { ender }\end{array}$ & $\begin{array}{l}\text { fent and une } \\
\text { flation, currenc }\end{array}$ \\
\hline griculture & d agricultural market. \\
\hline $\begin{array}{l}\text { Energy } \\
\text { environment }\end{array}$ & $\begin{array}{l}\text { Use of types of energy, oil a } \\
\text { natural gas, pollution and natu } \\
\text { resources. }\end{array}$ \\
\hline $\begin{array}{l}\text { pulation } \\
\text { igration }\end{array}$ & $\begin{array}{l}\text { Migratory flows, foreigners, } \\
\text { migrant labor market and } \\
\text { naturalizations. }\end{array}$ \\
\hline
\end{tabular}

Table 2 Competitivesness model

Source: Own wuth IMCO data

The World Economic Forum "WEF" carries out the analysis on twelve pillars to measure the competitiveness of countries in a microeconomic and macroeconomic environment, as well as institutions, policies and factors that determine the levels of economic prosperity in the short and medium term. 


\begin{tabular}{|c|c|c|}
\hline Pillars & Report & Items \\
\hline Institutions & $\begin{array}{l}\text { Security, property rights, } \\
\text { social, capital, checks and } \\
\text { balances, transparency and } \\
\text { ethics, public sector } \\
\text { performance and corporate } \\
\text { governance. }\end{array}$ & 17 \\
\hline Infrastructure & $\begin{array}{l}\text { The quality and extension of } \\
\text { transport infrastructure (road, } \\
\text { rail, water and air) and utility } \\
\text { infrastructure. }\end{array}$ & 8 \\
\hline $\begin{array}{l}\text { Macroeconomic } \\
\text { stability }\end{array}$ & $\begin{array}{l}\text { The level of inflation and the } \\
\text { sustainability of fiscal policy. }\end{array}$ & 4 \\
\hline Health & $\begin{array}{l}\text { Life expectancy adjusted to } \\
\text { health (HALE). }\end{array}$ & 11 \\
\hline $\begin{array}{l}\text { Higher education } \\
\text { and } \\
\text { entrepreneurship }\end{array}$ & $\begin{array}{l}\text { Workforce skills, digital } \\
\text { literacy, interpersonal skills, } \\
\text { and the ability to think } \\
\text { critically and creatively. }\end{array}$ & 8 \\
\hline $\begin{array}{l}\text { Goods Market } \\
\text { Efficiency }\end{array}$ & $\begin{array}{l}\text { Product market that a country } \\
\text { provides a level playing field } \\
\text { for companies to participate in } \\
\text { their markets, openings to } \\
\text { foreign companies and } \\
\text { encourage companies to } \\
\text { innovate. }\end{array}$ & 15 \\
\hline Market efficiency & $\begin{array}{l}\text { Labor market, flexibility, the } \\
\text { extent to which human } \\
\text { resources and talent } \\
\text { management can be } \\
\text { reorganized. }\end{array}$ & 10 \\
\hline $\begin{array}{l}\text { Financial market } \\
\text { satisfaction }\end{array}$ & $\begin{array}{l}\text { The availability of credit, } \\
\text { equity, debt, insurance and } \\
\text { other financial services, } \\
\text { stability, risks and } \\
\text { opportunistic behavior of the } \\
\text { financial system. }\end{array}$ & 9 \\
\hline $\begin{array}{l}\text { Technological } \\
\text { preparation }\end{array}$ & $\begin{array}{l}\text { Information and } \\
\text { communication technologies } \\
\text { (ICT). ICTs reduce transaction } \\
\text { costs and accelerate the } \\
\text { exchange of information and } \\
\text { ideas, improving efficiency } \\
\text { and innovation. }\end{array}$ & 8 \\
\hline Market size & $\begin{array}{l}\text { The size of the domestic and } \\
\text { foreign markets to which } \\
\text { companies in a country have } \\
\text { access. }\end{array}$ & 2 \\
\hline $\begin{array}{l}\text { Business } \\
\text { satisfaction }\end{array}$ & $\begin{array}{l}\text { Business dynamism, capacity } \\
\text { of the private sector to } \\
\text { generate and adopt new } \\
\text { technologies and new ways of } \\
\text { organizing work. }\end{array}$ & 9 \\
\hline Innovation & $\begin{array}{l}\text { Ability to innovate, the } \\
\text { quantity and quality of formal } \\
\text { research and development. }\end{array}$ & 6 \\
\hline 12 & & 107 \\
\hline
\end{tabular}

Table 3 Pillars of competitiveness

Source: Own obtained from World Economic Forum 2018-2019

\section{Basic concepts}

For Dussels (2001; quoted in Saavedra, 2012), he sees competitiveness as a process of dynamic integration of countries and products into international markets, depending on supply and demand conditions. For Padilla (2006; cited in Saavedra, 2012), competitiveness is related to the ability to increase the standard of living of the inhabitants, to generate sustained standards in productivity, to successfully enter international markets, etc.

Porter (1991) emphasizes the importance of the production process as a criterion that determines competitiveness. In the same sense, Alic (1987) conceptualizes competitiveness as the ability of companies to design, develop, produce and place their products on the international market amidst competition with companies from other countries. Urrutia (1994) considers it to be the ability to respond advantageously in international markets. Reinel (2005), Cabrera, et. al., (2011) business competitiveness is the ability of a company to sustain and consolidate itself in its market.

For the World Economic Forum (2010, p.4), the concept of competitiveness is "the set of institutions, policies and factors that determine the level of productivity of a country". Competitiveness refers to "the ability of companies to compete in markets, to increase their profits, in addition to growing" (OECD, 1992 cited by Gil, 2006).

\section{Context}

The vast majority of countries are evaluated by international institutions, allowing to know, under certain approaches, the financial status, the internal and external market, the GDP, the standard of living of people, the educational level, the level of science and technological innovation, among other indicators. The World Bank (2006) mentions that Mexico of its 100\% of its exports $88 \%$ is absorbed by the United States. This is a risk for Mexico, it needs to diversify and position itself in other international markets, foreseeing significant changes in the country of the United States and affecting its dependence on Mexico, since it ranks 46th in the competitiveness ranking. 


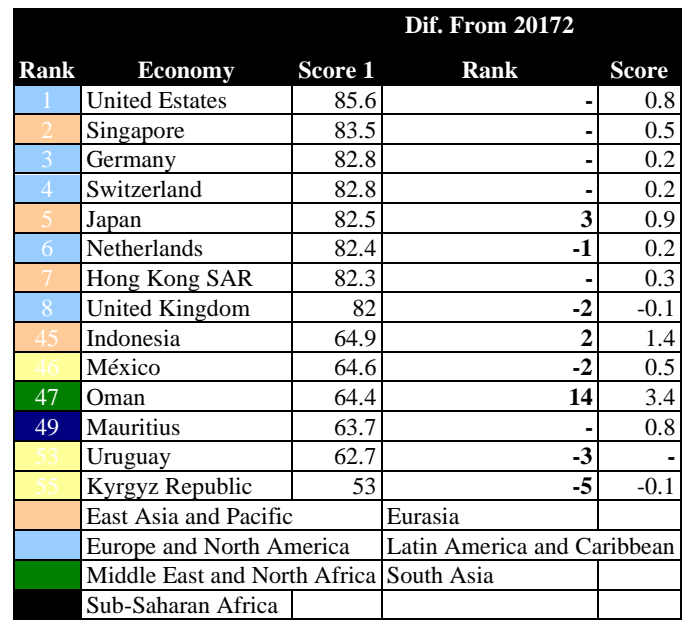

Table 4 The Global Competitiveness Index 4.0 2018 Rankings

Source: The Global Competitiveness Report 2018, World Economic Forum

In the last decade (2005-2014) all states increased their productivity, however, they did so at different rates. The states that increased the most were Zacatecas (157.1\%), Tabasco $(109.3 \%)$ and Querétaro (93.3\%). While those that had good growth Durango with (65.2\%), D.F. $(64.7 \%)$ and those with the lowest growth were Campeche (21.6\%) and Baja California Sur $(23.1 \%)$.

According to (INEGI, 2019) the Third Government Report (2019), it defines that at the end of 2018 the State's Gross Domestic Product (GDP) stood at 201,196 million pesos, which meant a participation of $1.13 \%$ of the total of national GDP, managing to rank 27th in the contribution ranking. In this same sense, its activity is concentrated in the tertiary sector with $60.42 \%$, secondary activities contribute $29.8 \%$ and primary activities $9.78 \%$. In terms of competitiveness, the Durango entity shows a favorable evolution, since according to the national Rancking it rose 3 places, going from 28th place to number 25 nationally (IMCO, 2018).

\section{Method}

Establishes a case study that integrates the design and validation of the instrument. The descriptive and interpretive method addressed to the content and elaboration of the items is addressed, which are directed at the definition of the variables and factors of the instrument used, which arises from the analysis of the concepts, studies and experience applied in the scientific method.
For this reason, it is important to focus efforts on addressing the content and internal consistency of the items.

The instrument is validated in its content with instruments $\mathrm{V}$ - Aiken and Cronbach's Alpha, considering the following points:

- The content of the instrument must be validated by experts (judges) who demonstrate their competence in the concepts of productivity and competitiveness.

- The instrument is focused on the concepts of competitiveness and productivity, which gives a line to determine the factors and variables.

- After its content validity. The instrument can be answered by managers or director of the company.

- The instrument measures competitiveness and productivity.

- The instrument is designed in such a way that it can be answered in complete freedom without meddling in situations of confidentiality.

- The instrument is used through the technological application that allows it to be available at any day and time.

- You can access statistical results immediately.

- Generate graphs of each element and in a segmented way.

- Generate a SWOT matrix.

- Generate a proposal for a strategic plan.

- Develops a projection as the instrument application is used.

\section{Validation of the V-Aiken instrument}

The procedure estimates the content validity and internal consistency of the instrument, considers the number of items, Clarity, Adequacy and Relevance. The instrument is based on the background, basic concepts, context, criteria and experience of the judges or experts.

CHAVEZ-SAMANIEGO, Rosendo, GUTIERREZ-MUÑOZ, Israel Iván and GRIJALVA-AVILA, Gerardo. Productivity and competitiveness in medium-large forestry-furniture and automotive companies in the Municipality of Durango, Dgo. Journal of Microfinance Planning and Control. 2020 
December 2020 Vol.6 No.18 10-21

The instrument has 42 items (see Annex A), clear, short and simple in the environment of productivity and competitiveness. The 11 judges are rigorously chosen and must meet a certain profile with experience, knowledge and verifiable managerial positions. Nine men and two women participate; six of them in the automotive industry and six in the forestry furniture industry.

The items are quantitatively valued by each expert on a four-point Likert scale $1=$ Nothing; 2 = Little; 3 = Enough; 4 = A lot, about elements of content validity: relevance, adequacy or mastery and clarity (Sireci \& Faulkner-Bond, 2014).

Once the statistics of the three approaches to the content of the judges have been calculated, the following formula is used per approach and generally to obtain the VAiken validation.

Formula $V=\frac{X-l}{K}$

Where:

$\mathrm{X}=$ average of expert ratings

$1=$ lowest rating value on the scale

$\mathrm{k}=$ range of possible values of the scale of assessment

The instrument defines two variables and six factors for each and the assigned items, as shown in Table 5. International and national organizations want to know the productivity and competitiveness of the countries; In this sense, the literature determines two variables influenced by their definitions, the context of organizations, the theoretical and conceptual framework, which in turn allow finding relevant factors and dimensions that directly affect companies.

\begin{tabular}{|l|l|r|}
\multicolumn{1}{c}{$\begin{array}{c}\text { Independent } \\
\text { Variables }\end{array}$} & \multicolumn{1}{c|}{ Factors } \\
& \multicolumn{1}{c|}{$\begin{array}{l}\text { Items } \\
\text { Dependent } \\
\text { variables }\end{array}$} \\
\hline & $\begin{array}{l}\text { Productivity } \\
\text { indicators }\end{array}$ & $20,21,25$ \\
\hline & Product quality & 19,24 \\
\hline & Capital & 30,40 \\
\hline & $\begin{array}{l}\text { Management } \\
\text { strategies }\end{array}$ & $9,10,11,14,15,16$ \\
\hline & Innovation & $12,22,23,28,33,34,35,41$ \\
\hline & $\begin{array}{l}\text { Human } \\
\text { Resources }\end{array}$ & $1,2,3,4,5,6,7,6,13,17,18,26$, \\
\hline & $\begin{array}{l}\text { Regional market } \\
\text { share }\end{array}$ \\
\hline & $\begin{array}{l}\text { Regional net } \\
\text { benefits }\end{array}$ \\
\hline & $\begin{array}{l}\text { Regional } \\
\text { management } \\
\text { strategies }\end{array}$ \\
\hline & Innovation & 36 \\
\hline & $\begin{array}{l}\text { Scientific and } \\
\text { technological } \\
\text { activity }\end{array}$ & 36 \\
\hline
\end{tabular}

Table 5 Instrument formation Source: Own

The validation of the instrument in its content, required the participation of 11 judges or experts, among them are academics with experience in manufacturing or forestry companies, people with more than 20 years of experience working in companies in the automotive and forestry sector with managerial positions. The blue line refers to the clarity of the items, the orange line refers to the adequacy of the items, the purple line refers to the relevance of the items with scales from 0 to 5 ; finally, the yellow line represents the value of $\mathrm{V}$ - Aiken on a scale from 0 to 1 . See Graphic 1 .

The reliability of each item must be greater than 0.7, the V-Aiken coefficient, and a critical value less than 0.5 is considered. In the case of the 42 items, they were above 0.7 except for item 1 with 0.58 .

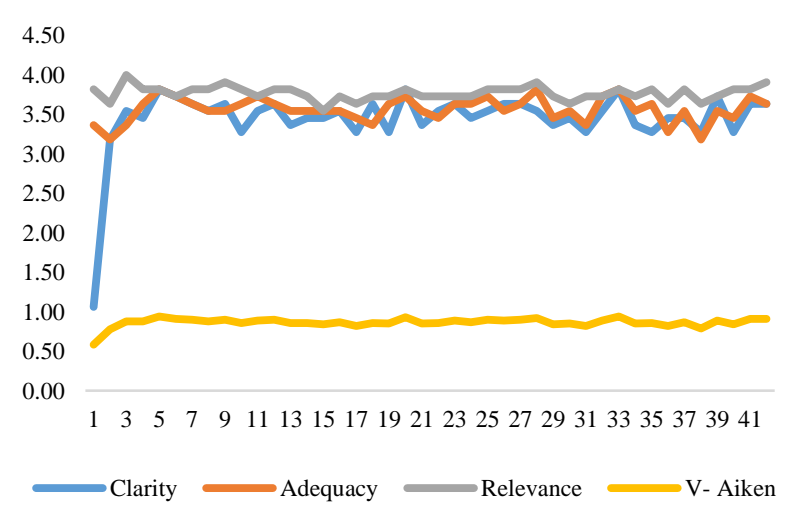

Graphic 1 V-Aiken Reliability

Source: Own

CHAVEZ-SAMANIEGO, Rosendo, GUTIERREZ-MUÑOZ, Israel Iván and GRIJALVA-AVILA, Gerardo. Productivity and competitiveness in medium-large forestry-furniture and automotive companies in the Municipality of Durango, Dgo. Journal of Microfinance Planning and Control. 2020 
The matrix of results of the validation of the eleven judges was greater than 0.7 in each item in the quality, adequacy, and relevance approaches. See Table 6.

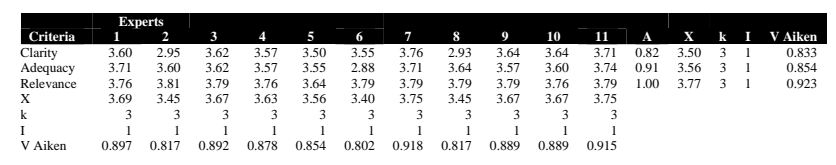

Table 6 Matrix of content by judge Source: Own

The average value thrown from the judges or experts of the items in the content approaches is shown in Graphic 2.

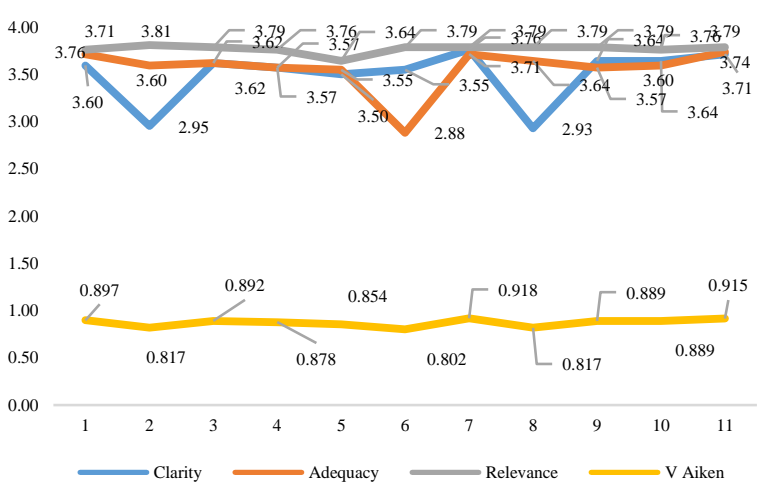

Graphic 2 Content values by judge Source: Own

The validity of the content is obtained using the variables: productivity with 0.846 and competitiveness with 0.845 and factors above 0.788. Each variable has 6 factors. See Table 7 .

\begin{tabular}{|l|r|}
\hline Variables and Factors & V - Aiken \\
\hline Productivity & $\mathbf{0 . 8 4 6}$ \\
\hline Productivity indicators & 0.818 \\
\hline Product Quality & 0.859 \\
\hline Capital & 0.843 \\
\hline Management strategie & 0.869 \\
\hline Innovation & 0.89 \\
\hline Human Resources & 0.802 \\
\hline Competitiveness & $\mathbf{0 . 8 4 5}$ \\
\hline Profitability & 0.788 \\
\hline Market Share & 0.869 \\
\hline Regional Net Profits & 0.909 \\
\hline E Management strategies & 0.818 \\
\hline Innovation & 0.872 \\
\hline
\end{tabular}

Table 7 Values by variables and factors Source: Own

\section{Reliability by Cronbach's Alpha}

The application of Cronbach's Alpha requires the use of the SPSS software to obtain the coefficient $\alpha$, where $\mathrm{n}$ is the number of parts, $\mathrm{k}$ is the part on which the deviation of the $\alpha$ coefficient is calculated, according to Lord and Novick (1968, p .89). The formula is as follows:

$\alpha=\frac{n}{n-1}\left(1-\frac{\sum_{K=0}^{n} \sigma_{K}^{2}}{\sigma_{x}^{2}}\right)$

The construction of the instrument was performed using the Likert scale $(1=$ never; $2=$ rarely; $3=$ regular; $4=$ frequently and $5=$ always) of ordinal category, whose purpose is to measure the relationship between elements of the variables and factors. The advantages of this instrument are:

- The instrument is focused on the concepts of competitiveness and productivity.

- The instrument can be answered by a manager.

- The instrument measures competitiveness and productivity.

- The instrument is designed to be answered in complete freedom without meddling in situations of confidentiality.

- The instrument must be simple, clear and requires little time available from the interviewees. The instrument must be simple, clear and requires little time available from the interviewees.

The instrument is applied to six companies in the automotive sector and six other companies in the forestry sector - medium furniture - large. The value obtained on the scale of $\alpha=0.912$. 
December 2020 Vol.6 No.18 10-21

\begin{tabular}{|c|c|c|c|c|}
\hline \multicolumn{2}{|c|}{ Reliability statistics } & \\
\hline $\begin{array}{l}\text { Cronbach's } \\
\text { alpha }\end{array}$ & $\begin{array}{ll}\begin{array}{l}\text { No. } \\
\text { elements }\end{array} & \text { of } \\
\end{array}$ & & & \\
\hline 0.912 & 42 & & & \\
\hline \multicolumn{5}{|c|}{ Statistics of total elements } \\
\hline & $\begin{array}{l}\text { Mean scale if } \\
\text { item has been } \\
\text { deleted }\end{array}$ & $\begin{array}{l}\text { Scale } \\
\text { variance if } \\
\text { item has } \\
\text { been } \\
\text { suppressed }\end{array}$ & $\begin{array}{l}\text { Corrected } \\
\text { total item } \\
\text { correlation }\end{array}$ & $\begin{array}{l}\text { Cronbach's } \\
\text { alpha if the } \\
\text { item has } \\
\text { been deleted }\end{array}$ \\
\hline V1 & 171.6666667 & 92.848 & -0.128 & 0.916 \\
\hline $\mathrm{V} 2$ & 171.8333333 & 90.455 & 0.172 & 0.912 \\
\hline V3 & 171.4166667 & 89.88 & 0.188 & 0.912 \\
\hline $\mathrm{V} 4$ & 171.6666667 & 92.848 & -0.128 & 0.916 \\
\hline V5 & 171.6944444 & 88.858 & 0.28 & 0.911 \\
\hline V6 & 171.6388889 & 82.777 & 0.836 & 0.904 \\
\hline V7 & 171.5833333 & 88.992 & 0.27 & 0.911 \\
\hline $\mathrm{V} 8$ & 171.6666667 & 83.333 & 0.924 & 0.903 \\
\hline V9 & 171.6944444 & 89.242 & 0.24 & 0.912 \\
\hline V10 & 171.6111111 & 83.512 & 0.806 & 0.904 \\
\hline V11 & 171.8055556 & 89.575 & 0.323 & 0.911 \\
\hline V12 & 171.6111111 & 83.269 & 0.832 & 0.904 \\
\hline V13 & 171.7222222 & 82.805 & 0.881 & 0.903 \\
\hline V14 & 171.75 & 93.053 & -0.13 & 0.918 \\
\hline V15 & 171.5033333 & 83.902 & 0.818 & 0.905 \\
\hline V16 & 171.8611111 & 85.868 & 0.762 & 0.906 \\
\hline V17 & 171.6666667 & 83.333 & 0.924 & 0.903 \\
\hline V18 & 171.4166667 & 92.568 & -0.096 & 0.916 \\
\hline V19 & 172.2222222 & 88.875 & 0.426 & 0.91 \\
\hline V20 & 172.3333333 & 88.545 & 0.334 & 0.911 \\
\hline V21 & 171.6944444 & 92.817 & 0.926 & 0.903 \\
\hline $\mathrm{V} 22$ & 171.75 & 90.144 & 0.178 & 0.912 \\
\hline V23 & 171.8611111 & 88.353 & 0.432 & 0.91 \\
\hline V24 & 171.9166667 & 86.952 & 0.56 & 0.908 \\
\hline V25 & 172.2777778 & 89.653 & 0.24 & 0.912 \\
\hline V26 & 171.8611111 & 85.848 & 0.765 & 0.906 \\
\hline V27 & 171.8333333 & 86.394 & 0.737 & 0.907 \\
\hline V28 & 171.7222222 & 83.128 & 0.847 & 0.904 \\
\hline V29 & 171.6666667 & 83.333 & 0.924 & 0.903 \\
\hline V30 & 172.1944444 & 89.989 & 0.282 & 0.911 \\
\hline V31 & 171.6111111 & 88.118 & 0.337 & 0.911 \\
\hline V32 & 172.1944444 & 88.151 & 0.53 & 0.909 \\
\hline V33 & 172.3333333 & 88.061 & 0.387 & 0.91 \\
\hline V34 & 171.6666667 & 87.697 & 0.427 & 0.909 \\
\hline V35 & 171.6666667 & 92.667 & -0.109 & 0.916 \\
\hline V36 & 171.5 & 85.303 & 0.653 & 0.907 \\
\hline V37 & 172.5555556 & 90.007 & 0.171 & 0.913 \\
\hline V38 & 171.75 & 90.144 & 0.178 & 0.912 \\
\hline V39 & 171.9166667 & 86.952 & 0.56 & 0.908 \\
\hline V40 & 171.8611111 & 85.848 & 0.765 & 0.906 \\
\hline V41 & 171.7222222 & 83.128 & 0.847 & 0.904 \\
\hline V42 & 172.1944444 & 89.989 & 0.282 & 0.911 \\
\hline
\end{tabular}

Table 8 SPSS Software

Source: Own

Although the result of general Alpha is very good, it is important to determine by factor the Cronbach's Alpha where results that are questionable are observed slightly below 0.6. However, it was decided to leave this factor due to the importance that the experts validated in their V-Aiken results. See Table 9.

\begin{tabular}{|l|r|r|r|r|}
\hline \multicolumn{1}{|c|}{ Factors } & \multicolumn{1}{c}{ Items } & \multicolumn{1}{c|}{ Average } & \multicolumn{1}{c|}{ Var. } & \multicolumn{1}{c|}{$\boldsymbol{\alpha}$} \\
\hline $\begin{array}{l}\text { Productivity } \\
\text { indicators }\end{array}$ & 3 & 8,407 & 0.678 & 0.566 \\
\hline Product quality & 2 & 3,694 & 0.22 & 0.536 \\
\hline Capital & 2 & 4,346 & 0.286 & 0.667 \\
\hline $\begin{array}{l}\text { Management } \\
\text { strategies }\end{array}$ & 6 & 21,550 & 4,463 & 0.909 \\
\hline Innovation & 8 & 26,479 & 5,214 & 0.808 \\
\hline Human Resources & 13 & 55,946 & 8,354 & 0.67 \\
\hline Cost effectiveness & 1 & NA & NA & NA \\
\hline Market share net & 1 & NA & NA & NA \\
\hline $\begin{array}{l}\text { Regional } \\
\text { benefits }\end{array}$ & 1 & NA & NA & NA \\
\hline $\begin{array}{l}\text { Regional } \\
\text { management } \\
\text { strategies }\end{array}$ & 1 & NA & NA & NA \\
\hline Innovation and & 1 & NA & NA & NA \\
\hline $\begin{array}{l}\text { Scientific } \\
\text { technological } \\
\text { activity }\end{array}$ & & & & \\
\hline
\end{tabular}

Table 9 Factor reliability

Source: Own

\section{Technology and innovation web application}

Technology and innovation are integrated to generate a Web application program of the productivity and competitiveness instrument on mobile devices that provides graphs, multivalent statistics, analysis tools, plans and projections.

The web application program allows companies to answer the instrument and immediately generate the following:

- Temporarily and transversally compares the relative position of small, medium and large local manufacturing companies in the Municipality of Durango.

- It provides a scale from 0 to 5 which can be translated into a rating from 0 to 100 for each entity, both at the indicator level and at the general level of each variable and by subscript, in order to know its performance.

- Lets make reasonable guesses about the effect of an increase in states' competitive position on investment and talent.

- It allows comparing the performance of different companies in different indicators, topic and at a general level.

- It is intended to have a particular and general productivity and competitiveness model in a partial way. 
- The model aims to carry out a particular and general SWOT.

- It allows to carry out an operational plan and follow-up.

\section{Results}

The results when applying the instrument to the 12 companies allows to measure the variables and factors; that is, on a scale of 0 to 5 , automotive companies have a productivity level of 4.55 and forestry-furniture companies 4.10 ; While at the competitive level, automotive companies have 4.10 and forestry-furniture companies 3.65 .

The generation of a software allows the use of the instrument in a web application. The companies participating in the study generate results instantly, and the following graph 3 of the system shows the level of competitiveness of the automotive companies.

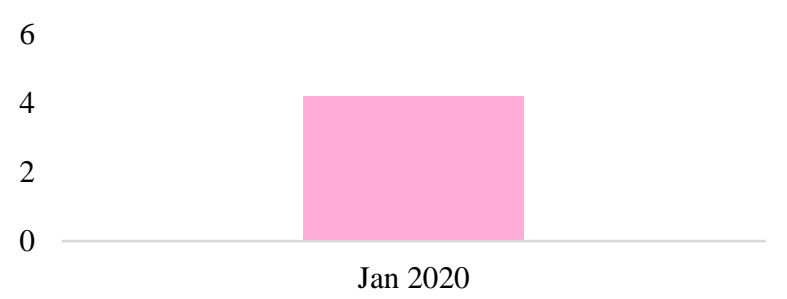

Graphic 3 Level of competitiveness and its factors Source: Own

The six factors established in the competitiveness variable are shown in Graphic 4 , radar type on a scale from 0 to 5 with the option of making a comparison of two different dates.

\section{Average by factors}

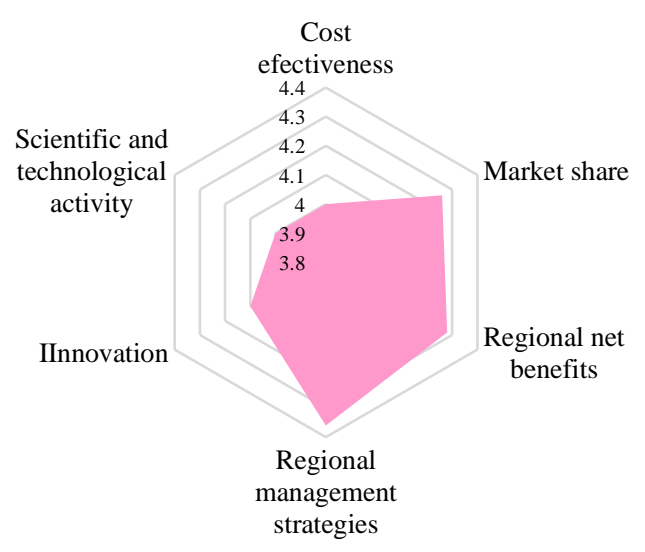

The system will be able to graph and monitor the behavior of the level of competitiveness and productivity of the companies. This means that as it is used they can visualize its behavior over time. It is also accompanied by a radar type chart that can compare two different dates. See Graphic 5.

\section{Productivity Results}

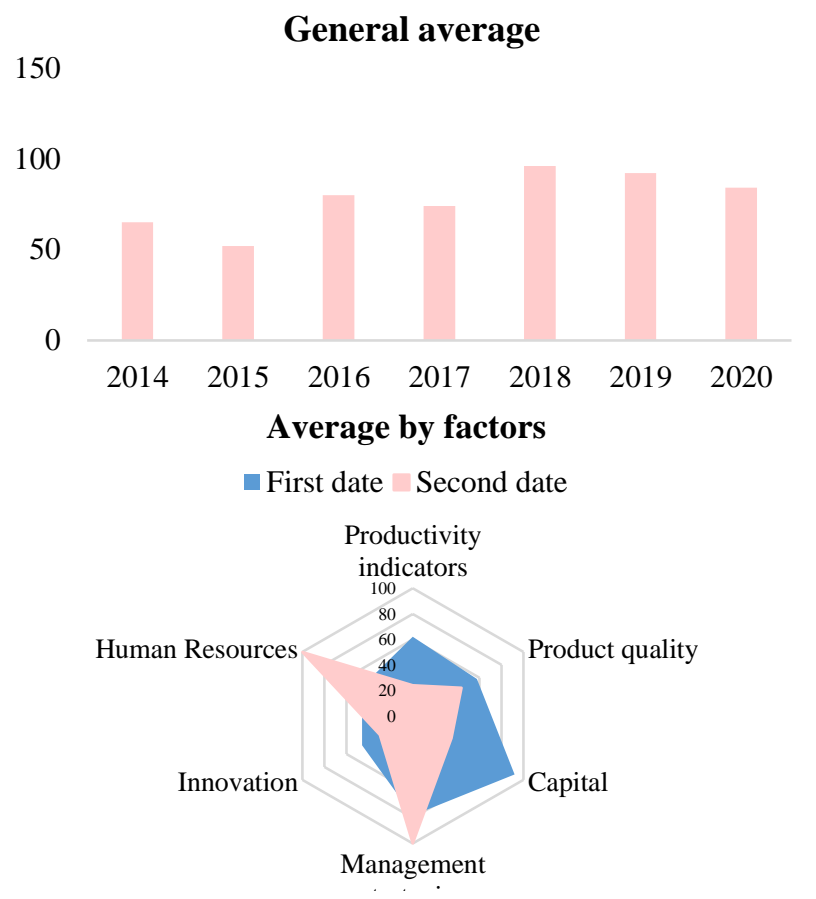

Graphic 5 Track during productivity time Source: Own

The system performs an analytical part (Know - How) that allows the SWOT to be cast; that is, it determines the internal analysis (Weaknesses and Strengths) and the external analysis (Threats and Opportunities).

\begin{tabular}{|c|c|}
\hline $\begin{array}{l}\text { Weaknesses } \\
\text { Threats }\end{array}$ & $\begin{array}{c}\text { Strengths } \\
\text { Opportunities }\end{array}$ \\
\hline $\begin{array}{l}\text { The company tries to } \\
\text { have a more economical } \\
\text { materials research and } \\
\text { development area. }\end{array}$ & $\begin{array}{l}\text { Regarding the life of the } \\
\text { company, it rarely affects } \\
\text { negatively: Inflation, currency } \\
\text { exchange, labor costs, taxes, } \\
\text { and access to loans to } \\
\text { capitalize. }\end{array}$ \\
\hline $\begin{array}{l}\text { The company rarely seeks } \\
\text { to have cheaper products, } \\
\text { it is interested in the need } \\
\text { for the product, } \\
\text { expectations of quality } \\
\text { and availability of }\end{array}$ & $\begin{array}{l}\text { Regarding the time of life, it } \\
\text { never negatively affects } \\
\text { structural reforms, legal } \\
\text { policies, macroeconomics, on } \\
\text { crime, violence, and public } \\
\text { confidence of politicians. }\end{array}$ \\
\hline
\end{tabular}

Table 10 SWOT

Source: Own 
Companies use the Balanced Scorecard methodology as a mechanism to follow up on their strategies aligned to the detected weaknesses of the organization as shown in Table 11.

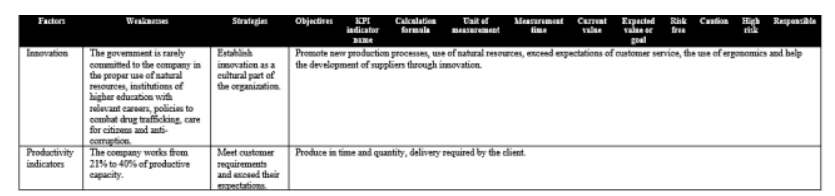

Table 11 Balanced Scorecard

Source: Own

\section{Gratitude}

I am grateful for the funding of this article to the Polytechnic University of Durango.

\section{Conclusions}

The research achieves its objective by determining the variables and factors that allow generating an instrument validated by the $\mathrm{V}$ Aiken and Cronbach's Alpha methodology in its content, which allows applying this instrument in a case study with 12 medium-large companies of the two important sectors: forestry - furniture and automotive in the municipality of Durango.

\section{Anexo A}

Instrument for competitiveness and productivity of companies.

1. Does the director prepare professionally continuously?

2. Are managerial positions filled by people who have experience and knowledge of the functions of the areas?

3. Does the company have a relationship with higher education institutions?

4. Do you locate the competitive human resource to occupy key spaces within the company in the region?

5. Do staff receive ongoing training throughout the year?

6. How often is the performance evaluation of workers carried out?
7. Does the professional newly incorporated into the company receive adequate induction, training and / or training?

8. Is a certain level of English required by the workers to carry out their tasks?

9. Are there ongoing operational plans to organize staff and seek better results?

10. The following variables: Mission, vision, values, objectives, policies and review of results. Have they been defined and controlled in the company?

11. Are there specific and updated organization manuals in writing?

12. Have you identified who your main suppliers are and keep your work history up to date?

13. Do you keep the procedure updated to efficiently communicate the work plans?

14. Is there a: preventive, predictive maintenance program, work orders, adequate and sufficient tool to carry out work orders?

15. Does the company plan to access the international market, stay in it or strengthen itself?

16. Is the plan to access, stay in or strengthen the international market operating?

17. Do they carry out health campaigns for the benefit of workers such as: Influenza, HIV / AIDS, infant mortality, alcoholism and drug addiction, and prevention of automobile accidents?

18. Is the integrity of personnel protected by: Adequate personal safety equipment, evacuation drills, preventive actions to avoid unsafe conditions, unsafe acts, social security, medical service, order and cleanliness in work areas, bathrooms and kitchens?

19. Does the company count and apply: Quality plans, procedures to control and monitor the production process, application of lean manufacturing tools and application of six sigma tools?

CHAVEZ-SAMANIEGO, Rosendo, GUTIERREZ-MUÑOZ, Israel Iván and GRIJALVA-AVILA, Gerardo. Productivity and competitiveness in medium-large forestry-furniture and automotive companies in the Municipality of Durango, Dgo. Journal of Microfinance Planning and Control. 2020 
20. How often does the company update its indicators and follow up to measure productivity?

21. How often do you evaluate the capacity of the process?

22. Do the suppliers fulfill the quantity, quality and on time the raw material orders?

23. Does the company fulfill the client in the quantity, quality and on time the orders of the finished product?

24. How often does the company update its indicators and follow up to measure the quality of its products?

25. Do you work from $80 \%$ to $100 \%$ of the capacity of the production lines most of the year?

26. Does the company have: staff motivation processes, productivity incentive programs, training programs, support programs to continue some undergraduate level preparation, worker programs to provide ideas for process improvement?

27. Do you consider the company as: a good place to work, a place of job growth, with a fair salary and a place with gender equality?

28. Do you design and develop your own products?

29. Is there research and development of cheaper materials?

30. Do you have your own manufacturing for the production process?

31. Has the company generated: intellectual property, patents and technological development?

32. Does the company seek to have cheaper products, meet the needs and expectations of quality, and have availability of the latest technologies?

33. How often does the client request containing actions?
34. Do you have customer service procedures, people trained to assist you, tools to stop or detect problems, and analysis of solutions for them?

35. Are you concerned with meeting the quality requirements demanded by the client, as well as the reduction of product costs, the fair prices you pay for product design and processes?

36. Do you provide quality infrastructure to the company: land roads, rail and air land transport to transport the product?

37. Does the government or external company provide quality services to the company in: energy supplies, drinking water, garbage collection and telephony?

38. Regarding life time, the following aspects have negatively and significantly affected the following: Inflation, currency exchange, labor cost, taxes and access to loans to capitalize?

39. Regarding life time, the following aspects have negatively and significantly affected the subsequent: structural reforms, legal, macroeconomic policies, on crime, violence and public confidence of politicians?

40. Does the company encounter: a commercial rivalry, access to the international market, stable economic performance and a growing demand for its products?

41. Is the government committed to the company in: adequate use of natural resources, higher education institutions with relevant careers, policies to combat drug trafficking, citizen care and anti-corruption?

42. Are there compliance with: transparency of use of resources, judicial independence, legal framework for all, trust of banks with government policies and support for the installation and opening of businesses?

\section{References}

ALIC, J. (1987). Evaluating industrial competitiveness at the office of technology In society. New York: Basic Book Inc. 
CABRERA, A., LÓPEZ, P. and RAMÍREZ, C. (2011). "Business competitiveness: a conceptual framework for your study", Research documents. Business Administration. Colombia: Ulloniversidad Foundation. Central, 4 (1). Retrieved on September 19, 2013 from http://www.ucentral.edu.co/sites/publicaciones/i mages/stories/subportal_publicaciones/publicac iones/DocumentosAdministracion4.pdf.

DUSSEL, E. (2001). An analysis of the competitiveness of Apparel exports in Central America using the programs and can and magic methodology. Series studies and perspectives (1). Recovered from http://repositorio.cepal.org/bitstream/handle/11 362/4875/S01030302_es.pdf?sequenc $\mathrm{e}=1$ \&isAllowed=y

WORLD ECONOMIC FORUM (2010). The Global Competitiveness Report 2009-2010. http://www3.weforum.org/docs/WEF_ GlobalCompetitivenessReport_2009-10.pdf

GIL BOLÍVAR, FABIO ALBERTO (2006), "The innovation and scientific Foresight technology as a means of Learning and the social construction of the future ", in Scientific Threshold magazine, no. 009, Mexico: Manuela University Foundation Beltran.

MEXICAN INSTITUTE
COMPETITIVENESS FOR
Inflection Point. Available in:
http://www.imco.org.mx/libroweb/
InformeEstatal.pdf [2018]

STATISTICS NATIONAL INSTITUTE, GEOGRAPHY AND COMPUTERS (INEGI) (2020), Indicators Internationals. Available in: www.inegi.gob.mx/lib/buscador/busqueda.a spx?s=inegi\&textoBus=producto $\% 20$ interno $\% 2$ 0bruto\%20trimestral\%20indicadores\%20intern acionales $\& \mathrm{i}=\& \mathrm{e}=\&$ seccionBus $=$ docit $[$ [March, 2020]

LORD, F. M., \& NOVICK, M. R. (1968). Statistical heories of mental test scores. Reading, Massachusstes: Addison-Wesley.

\footnotetext{
ORGANIZACIÓN PARA LA COOPERACIÓN Y EL DESARROLLO ECONÓMICO (2017), OECD Integrity Review of Mexico: Taking a stronger stance against corruption, OECD Publishing, París.
}

PEIRANO, CLAUDIA (2014). The Competitiveness Pyramid and its Application to the Competitive Analysis of the Forest sector. Scientific Magazine "Vision of the Future" Vol. 188, no. 1, January-June, pp. eleven-136 Misiones, Argentina.

PORTER, M. (1991). Competitive Advantage, Argentina. CECSA.

PORTER, M.: "What is Strategy", Harvard Business Review, Nov/Dec 1996.

PORTER, MICHEAEL E. (2009), Competitive strategy. Techniques for the analysis of the industrial and competition sectors, Mexico: Grupo Editorial Patria.

REINEL, J. y BERMEO, E. (2005). Cost guidelines as sources of competitive advantage. Management Studies Magazine. 81-103.

SAAVEDRA, M. L. (2012). A proposal for determining competitiveness in Latin American SMEs. Thought \& Management, 33 (50) 93-124. Retrieved on January 20, 2014 http://www.redalyc.org/pdf/646/64624867005. pdf.

SIRECI, S., \& FAULKNER - BOND, M. (2014). Validity evidence based on test content. Psicothema, 26(1), 100-107. 